\title{
Além do bem e do mal: \\ o poder em Maquiavel, Hobbes, Arendt e Foucault
}

\author{
Beyond good and evil: \\ perceptions of power in Machiavelli, Hobbes, Arendt, \\ and Foucault
}

O que é poder? A pergunta não é nada nova. A questão do poder é colocada desde que o ser humano começou a pensar sobre si mesmo: com o poder, os fatos básicos da coexistência humana estão submetidos a exame. Muitas são as respostas que foram dadas à questão do poder na história. Entre elas, vale a pena destacar a famosa definição de Max Weber - uma referência para toda e qualquer investigação sobre o poder: o poder "como cada chance de impor, dentro de uma relação social, a vontade própria mesmo contra relutância, não importando em que essa chance se baseia" (Weber, 1922, cap. 1, \$16). ${ }^{1}$ A definição é clássica e quase atemporal. Quase, pois na verdade o poder nunca permaneceu o mesmo. No decorrer do tempo ele trocou permanentemente sua imagem, seu nome e também seu lugar. Quem se perguntar sobre o poder depois da modernidade o encontrará com outras representações, outro nomes e outro lugares.

$\mathrm{O}$ que nós hoje denominamos poder era designado pelos gregos por meio de diversas palavras: arché, dynamis, kratos, tyranos e despoteia. $\mathrm{O}$

É professor da Universidade de Regensburg (Regensburg, Baviera, Alemanha). E-mail: karlfriedrich. herb@politik.uni-regensburg.de

Uma primeira versão deste escrito foi apresentada no quadro de uma série de conferências destinadas aos pós-graduandos de Ciência Polílica da UnB. Oautorgostaria de agradecerà profa. Marilde deMenezeseao prof. Paulo Nascimento, ambos do Instituto de Ciência Política da UnB, eao prof. Gerson Brea, do Departamento de Filosofia da UnB, pelo estímulo e pelas críticas ao presente texto. A tradução das citações foi feita por Roberto Cataldo Costa. 
poder político - arché politike - encontrava-se dentro dos muros da polis, na comunidade política dos cidadãos. Quando esses muros caíram e o latim tornou-se a língua da filosofia, o poder passou a ser chamado de auctoritas e potentia e a mover-se entre ofício e prestígio, estratégia e instituição (cf. Kobusch e Oeing-Hanhoff, 1980, p. 585-588). No contexto alemão, a palavra poder tem sua origem nas formas verbais können e vermögen (poder e ser capaz). No mundo dos conceitos, o poder tem, desde o início, um concorrente: a violência. Violência (Gewalt) é derivada do verbo walten (reinar) e significa algo como ter força, dispor sobre alguma coisa ou reger. Desde então, poder e violência encontram-se em uma luta acerca da supremacia conceitual - com alguma vantagem do lado do poder. Todavia, muitas vezes eles são usados indistintamente e ocupam o mesmo campo semântico.

Isso é até hoje assim. No alemão, também oscilamos entre poder e violência, quando, na verdade, falamos da mesma coisa. E, como sempre, atrás de tal indecisão, esconde-se um grave problema filosófico. Lá onde deliberamos sobre o poder, falamos sem inibições de violência. Numa tacada, definimos conceitos como concentração de poder e monopólio de violência. E o poder político vemos de preferência nas mãos do Estado, perante o qual não sentimos tanto medo. Afinal, a autoridade do Estado, como todas as constituições modernas asseguram, provém de nós, o povo. Apesar disso, sempre temos alguma desconfiança do poder. Para grandes céticos, como Jacob Burckhart, o poder é essencialmente mau (Burckhardt, 2002, p. 25) - e muitos receiam, ainda hoje, que o poder possa perverter o caráter. No Brasil, o receio parece ser igualmente patológico e legítimo. Diariamente, a mídia alimenta tais receios. Todavia, mesmo aqui, precisamos ser cautelosos. Não contaminou o poder da mídia, há muito tempo, aquela confiança que no século XVIII foi atribuída à esfera pública, ou seja, ao quarto poder?

O que é então poder? Sempre algo ameaçador? Depende de repartições públicas? Concede charme e carisma? Mostra-se em instituições? Ou se esconderia dentro de sistemas e atrás de muros? São questões como essas que gostaria de investigar no contexto moderno - e nesse contexto dar a palavra a quatro autores. Para todos eles, o questionamento sobre o poder é fundamental - e todas as quatro repostas tiveram influência marcante na filosofia política. Nesse caso, como de costume, as respostas são tão diversas quanto a diversidade das perguntas. $\mathrm{O}$ que une esses autores é uma tendência de situar o poder para além do bem e do mal, ou seja, todos eles oferecem 
certa apologia do poder. O que os separa são as bases dessa defesa bem como as concepções do modo como poder e direito, ser e dever, se relacionam.

\section{Maquiavel ou como lidar com o poder}

Em 1532, foi publicada a notória e famosa obra Il principe. Isso fez de Maquiavel - que a vida inteira aspirou, em vão, ao poder - o primeiro clássico da modernidade política. Sua atividade política prova a impotência, sim, a ineficácia do conselheiro e a fragilidade da reflexão política. Apesar de todas as ambições, a carreira política tão desejada pelo florentino fracassou. E sua relação para com os governantes permaneceu precária. Poderia ter tido sucesso? Ou seja, teria Maquiavel encontrado acesso ao poder, se tivesse seguido suas próprias máximas? A questão é especulativa: fato é que, a partir de sua obra - nascida de uma frustração -, Maquiavel se tornou o herói da teoria política. Seu nome ficou ligado eternamente ao poder. E até hoje o maquiavelismo representa - justa e injustamente - a busca sem escrúpulos pelo poder. Galileo da política (Cassirer, 1966, p. 130) ${ }^{2}$, Feiticeiro do poder, esteta da violência (König, 1979, p. 338), Educador do mal (Strauss, 1958, p. 9) - esses são alguns dos rótulos mais comuns. Desde o início, a história da recepção da obra de Maquiavel confunde-se com uma história de escândalos.

Sem dúvida, suas reflexões sobre o poder são, ao mesmo tempo, inovadoras e escandalosas. Sua receita para o príncipe não tem nada mais em comum com os espelhos dos príncipes (Fürstenspiegel), ou seja, com aqueles manuais bem intencionados dos príncipes antecessores. Pelo contrário. Ele documenta o desencanto completo do mundo político da Idade Média. Na história não há a ação de Deus, guiando o destino dos homens segundo um plano oculto de sua pretensa sabedoria. E também a natureza não tem nada a ver com um reino claro de fins e propósitos, que reserva para o indivíduo e a comunidade um lugar seguro e estável. No universo do principe de Maquiavel reinarão a fortuna, o destino e a necessidade. Estes determinarão agora os parâmetros da organização de toda política humana.

O sóbrio olhar de Maquiavel descobre uma política totalmente terrena e um ser humano completamente profano. O desencanto do mundo externo se funde com o desencanto da natureza humana. $O$ homem não é mais aquele ser pacífico e sociável tão desejado pelos filósofos da antiguidade e

Cf. Cassirer (1966, p. 130): "Assim como a dinâmica de Galileu se tornou a base de nossa moderna ciência da natureza, Maquiavel abriu um novo caminho para a ciência política". 
pelos teólogos da idade média. Não é mais um zoon politikon, um animal rationale e sociale, ou um homo politicus, mas, sim, um indivíduo dominado por interesses e dirigido por desejos inesgotáveis. Ambição - esse o título para essa antropologia pessimista do príncipe. Ela impulsiona a ação dos humanos para as mais diversas direções e se realiza nos mais diversos motivos da avidez humana: na sede de glória, no desejo de posse, de lucro e de poder. A ambição pelo poder é central. O poder deixa de ser um vício dos poderosos e torna-se uma constante da natureza humana antes de toda política. Dominar o outro para não ser dominado - esse o moto dessa nova antropologia.

Maquiavel observa o comportamento do homem sem nenhuma piedade, e projeta uma lista negativa do caráter humano. "Pode-se dizer em geral dos seres humanos que eles são ingratos, inconstantes, falsos, hipócritas, temerosos e gananciosos" (Machiavelli, 1988, cap. XVII). Aquele que deseja conquistar e manter o poder político tem que contar com essa dimensão negativa; tem que partir do pressuposto, nas palavras do próprio Maquiavel, "de que todos os homens são perversos, e que seguem sempre suas más inclinações, assim que tenham uma oportunidade" (Machiavelli, 1983, I, 3). Esse caráter maligno da natureza humana está longe de ser uma hipótese pessimista ou um registro momentâneo de crise. Trata-se, antes, de um triste fato que determina toda política. Maquiavel conta com o pior e define-se de acordo com a produtividade do mal. O príncipe é aquele que permite a fertilidade da maldade - aquele que cuida das flores do mal.

Quem parte de tais fatos não deve ter nenhuma consideração por normas no cotidiano da política - e nenhuma pretensão de transmitir valores. Afinal, não interessa a ele a vida política, como ela deveria ser, e sim como ela é. O que está em jogo são os conhecimentos de fatos - o cotidiano do poder. Sem hesitação, Maquiavel destrona duas grandes autoridades que governaram normativamente, até então, a doutrina da política: a religião e a moral. Ambas perdem a tutela sobre o poder político. Com toda franqueza, Maquiavel declara a religião como instrumentum regni - como instrumento de domínio - e coloca-a a serviço da política. A religião serve como cimento da comunidade política e como uma unidade de resgate nos casos em que a virtù do indivíduo está prestes a sucumbir. O mesmo ocorre com a moral - também ela tem que desaparecer da política - ou se subordinar a essa ordem. A moral da política transforma-se em política da moral. 
Para Maquiavel, normas e valores são fundamentalmente puras imaginações (Machiavelli, 1988, cap. XV), que somente serão levadas a sério se servirem a objetivos políticos. Dois exemplos: o antigo virtus vai se transformar no moderno virtù. Enquanto no mundo antigo a virtude se confundia com a boa política que se orientava pela justiça e pelo bem comum, em Maquiavel, a virtude passa a situar-se entre o bem e o mal - a partir de agora a virtude torna-se uma ação política bem-sucedida. $\mathrm{O}$ mesmo destino acaba sofrendo a antiga prudência. Se a prudentia até então se preocupava com o equilíbrio entre utilidade e justiça, agora ela deve ser restringida a um mero cálculo de benefícios. Maquiavel prefere fórmulas simples. Prudente é aquilo que serve. A nova prudentia dissipa todos os escrúpulos morais. Em caso de dúvida, todos os meios são justos - sejam eles legítimos ou ilegítimos. O príncipe dispõe de ambos os meios, ele governa com astúcia e violência. Maquiavel leva isso a sério: engano, crueldade e quebra de palavra (cf. Machiavelli, 1833, p. 26) tornam-se meios legítimos da política. Sobre o emprego desses meios, decide o príncipe unicamente por meio do cálculo de poder. Como todos sabemos: o fim justifica os meios. O que justifica o fim, no entanto, não diz Maquiavel. Sua razão de Estado está sob o ditado dos fatos: ela não quer mais saber do telos, do fim último da política e da moral do poder. Um olhar sóbrio-cruel sobre os fatos torna visíveis não somente os mecanismos mas também os abismos do poder. De outro lado, os próprios fundamentos jurídicos do poder permanecem ocultos. A pergunta pela legitimidade do poder foi colocada por outros.

\section{Hobbes ou como justificar o poder}

Até hoje permanece controverso quem inaugurou a política moderna. Maquiavel ou Hobbes? Hobbes mesmo resolve a polêmica a seu favor. Convicto, se declara o fundador da filosofia do direito moderno, e contempla sua obra como aquela que pela primeira vez trata a política de modo realmente científico (cf. Hobbes, 1837-1845, p. 467). Tais pretensões de poder intelectual eram alheias a Maquiavel. Já em Hobbes elas não vêm do nada. Ele está totalmente convencido de que a ciência sozinha irá colocar um fim na velha guerra secular das canetas e na atual guerra das espadas. Desse modo, Hobbes anuncia o credo da modernidade: "Scientia propter potentiam" (Hobbes, 1967, I, 6). Em suma: saber é poder. Como Maquiavel, Hobbes desenha sua 
teoria sob o impacto da crise: lá, a luta pela supremacia no norte da Itália; aqui, as conturbações e tumultos da guerra civil na Inglaterra. A experiência de anarquia é inspiração para o novo conceito de poder. Como Maquiavel, Hobbes é um grande cético da natureza humana. "Homo homini lupus est" (Hobbes, 1966, De cive, Ded.) é o primeiro princípio de sua antropologia política. O homem é o lobo do homem - pelo menos enquanto ele ainda não vive sob o domínio do Leviatã.

Também Hobbes é inicialmente fascinado pela empiria do poder. Quando jovem, traduz a Guerra do Peloponeso, de Tucídedes, e procura, nas lições da história, a moral para a política. Desde cedo, percebe que nenhum caminho conduz da civil history para a civil science, da história para a ciência (Hobbes, 1991, cap. IX). A partir do conhecimento factual, não é possível justificar reivindicações normativas. Uma teoria filosófica do poder necessita de outros fundamentos (Herb, 2005, p. 217-227). Maquiavel pergunta: como o poder pode ser conquistado e mantido? Hobbes, por sua vez, quer saber o que torna o poder legítimo. Ele coloca a quaestio juris. Em outras palavras: ele procura pela legitimação filosófica do poder.

Hobbes traduz o conceito de poder para a linguagem do contratualismo. Com Hobbes, o modelo do contrato torna-se o protótipo para a justificação do estado moderno. O poder - essa é a ideia básica do Leviatã - pode ser justificado tão somente a partir do livre arbítrio de cada um. Antes, contudo, tem de ser esclarecido se e por que o poder é de modo geral necessário. Hobbes recorre ao argumento do estado da natureza, e seu diagnóstico do estado natural da humanidade é muito claro. Não há harmonia; o conflito determina a conditio humana.

Sendo assim, o que quer que seja consequente com um tempo de Guerra, onde todos os homens são inimigos de todos os outros, também o é com o tempo em que todos os homens vivem sem outra segurança além da que lhe proporcionam sua própria força e sua própria criatividade. Nessas condições, não há lugar para a Indústria; porque seu fruto é incerto e, consequentemente, nenhuma cultura da Terra, nenhuma navegação, nenhum uso das mercadorias que possam ser importadas pelo Mar, nenhuma construção conveniente, nenhum Instrumento para se deslocar ou deslocar coisas que requeiram muita força; nenhum Conhecimento da face da Terra, nenhum registro do tempo, nada de Arte, nada de Letras, nada de Sociedade e, pior do que tudo, medo permanente e risco de morte violenta; e a vida do homem, solitária, pobre, sórdida, embrutecida e curta (Hobbes, 1991, cap. XIII). 
Enquanto sujeitos de liberdade e de poder, os homens conduzem uma luta permanente por sobrevivência e reconhecimento - uma luta em que há somente perdedores. Pelo fato de todos possuírem um direito natural sobre tudo e, assim, tudo estar no poder de cada um, a concorrência ruinosa é inevitável. Sob tais condições, qualquer estratégia de poder, mesmo a agressão preventiva, está condenada ao fracasso. Ou, nas palavras do próprio Hobbes, "se todos possuem o poder igual, então ele não significa nada" (Hobbes, 1966, De homine, VI, 6). A partir desse equilíbrio devastador entre poder e impotência - a "guerra de todos contra todos" (Hobbes, 1991, cap. XIII) -, o contrato se apresenta como única saída possível: ele monopoliza o poder nas mãos do soberano. Visto a partir do caos do estado natural, o poder do Estado irradia desde o início uma luz brilhante: ele garante autopreservação individual e paz social. Para além de todos os seus motivos, o poder, aqui, serve a um propósito positivo. Ele domina o medo de uns diante dos outros e pacifica suas relações. Somente esse poder está em condições de estabelecer a paz entre os homens.

O contratualismo de Hobbes descreve o caminho legal para o poder. Todos concordam contratualmente em abdicar, em favor do soberano, de seu precário direito a tudo. A partir de agora, ele pode dispor, sem concorrência, sobre seu poder natural: o soberano recebe o monopólio do exercício legítimo de coerção. O contrato realiza ainda mais: ele autoriza o soberano a agir em nome da parte contratante. Por meio desse ato, o soberano torna-se o representante do cidadão. Hobbes investe tudo a fim de revestir o soberano com a plenitude máxima do poder. Como legislador, ele é legibus solutus - excluído de todas as leis. Monarquia, aristocracia, democracia - todas elas dispõem sobre a mesma quantidade de poder absoluto. Aqui não há, para Hobbes, possibilidades de negociação: esse absolutismo é a condição de existência do direito positivo e da paz social. Na figura do soberano, confluem poder e direito, pois o que é válido no direito depende somente de sua decisão soberana. "Auctoritas, non veritas facit legem" (Hobbes, 1991, cap. XXVI). Não a verdade, mas sim o poder decide o que é certo e justo.

Quem deseja, aqui, uma demarcação institucional do poder do soberano ficará desapontado. Hobbes reage de forma alérgica a exigências de separação de poderes e de controle da violência. Ele vê nisso uma contradição para a soberania. Uma constituição mista levaria o soberano à loucura. Onde faltam as instituições, a moral deve ajudar. Hobbes confia na moral do soberano. 
Em contradição com Maquiavel, ele submete o soberano à exigência das leis naturais, aos comandos de Deus e à razão natural. Aparentemente, Hobbes acredita ser possível, com apelos morais, disciplinar o poder. Hobbes ignora o perigo de que a posse de tão grande poder pudesse vir a corromper o soberano. Mais ainda: ele aposta nos efeitos positivos do uso do poder e espera até mesmo uma purificação da busca pelo poder. Podemos duvidar se essa confiança é mesmo compatível com as próprias premissas antropológicas de Hobbes. Afinal, ele assume para o homem uma vontade insaciável de poder. Por que, então, justamente o soberano deveria estar livre desse "perpetual and restless desire of Power after Power" (Hobbes, 1991, cap. XI) - esse desejo inesgotável de poder e mais poder?

Não é, portanto, sem razão que os sucessores de Hobbes permanecerão desconfiados e procurarão formas eficientes para delimitar o poder. Para eles, a pergunta pelo poder coloca-se imediatamente como pergunta por suas fronteiras e barreiras. O liberalismo fará dessa questão seu objetivo principal. O controle do vigilante (custodes) transformar-se-á no novo desafio da teoria do poder: poder legítimo também deve ser domado. John Locke coloca em xeque o Leviatã por meio da lei natural e da teologia - ele quer principalmente limitar a soberania (cf. Locke, 1990). Montesquieu, por sua vez, busca refúgio na separação dos poderes do estado. O poder deve ser restringido por meio do poder: "le pouvoir arrête le pouvoir"(cf. Montesquieu, 1951, XI, 4). Rousseau joga outra carta: ele vê na democracia um poder novo, que não ameaça a ninguém, porque parte de todos (cf. Rousseau, 1964). A souveraineté une et indivisible $e^{3}$ não precisa de nenhum guardião da constituição. Só a quinta república francesa vai se emancipar da herança de Rousseau. Para além do Atlântico, também não é difícil perceber certa desconfiança da soberania e do poder do povo. Os federalistas procuram, com seu realismo, a proteção das instituições - checks and balances - como resposta ao estigma humano (cf. Hamilton, Madison e Jay, 2005). Aqui, é como se o ceticismo de Hobbes acerca do ser humano se deslocasse para os detentores do poder democrático.

Por mais diversos que sejam, esses esforços para disciplinar o poder colocam marcas no caminho do estado de direito liberal, como nós o conhecemos hoje. Poderíamos classificar Hobbes nessa tradição liberal? Algumas

Cf. Constitution française du 3 septembre 1791, Préambule, art. 1, e Déclaration des droits de I'homme et du citoyen de 1789. 
evidências levam a isso: afinal, ele confere ao poder uma origem democrática e procura limitar seu raio de ação. A vida interior dos súditos é um tabu para o poder de estado. Já por isso, Hobbes não pode ser considerado precursor do totalitarismo. Hitler e Stalin tiveram, certamente, outros mentores.

\section{Hannah Arendt ou onde aparece o poder}

Totalitarismo: essa palavra nos conduz à terceira teoria do poder e com isso diretamente ao século XX. Origens do totalitarismo - assim se chama o livro em que Hannah Arendt tratou dos regimes violentos do século XX. Já o título reflete a tentativa de especificar aquilo que é inédito e comum no nazismo e no stalinismo. Como sabemos, essa investigação torna-se um marco decisivo na pesquisa do totalitarismo, e promove a autora internacionalmente.

Nascida como judia na Alemanha e se tornado apátrida pelo regime nazista, Hannah Arendt não teve como se esquivar do fenômeno do totalitarismo. A princípio, ela desejava se dedicar exclusivamente à filosofia. No entanto, após 1933, Arendt encontra seu tema no conflito entre filosofia e política, entre saber e poder. Hoje celebrada como a grande pensadora política do século XX, Arendt compreendeu-se a si mesma como pária na sociedade fechada dos filosófos. Até mesmo o título de filósofa política rejeitou veementemente: "Eu não pertenço à liga dos filósofos. Minha profissão - se é que se pode falar em profissão - é a teoria política. A propósito, eu nem considero ter sido admitida na liga dos filósofos" (Arendt, 1996, p. 44).

O confronto com o totalitarismo a conduz para a primeira reflexão sobre o fenômeno do poder. A historiografia empreendida por Hannah Arendt quer conceituar tanto os elementos inéditos como todas aquelas tradições destruídas pelos regimes totalitários. Isso se mostra, acima de tudo, na pretensão absoluta de poder nesses regimes. De acordo com sua tese, esses regimes cunham "representações de poder, até agora desconhecidas" (Arendt, 2009a, p. 864) e estabelecem "um princípio totalmente novo de realidade e poder" (Arendt, 2009a, p. 867). É característica central de todo poder totalitário emancipar-se inteiramente de toda e qualquer legitimação democrática. Em vez de apoiar-se no consenso dos cidadãos, ele confia exclusivamente em sua própria força e potência (Arendt, 2009a, p. 865). O poder totalitário alimenta-se única e exclusivamente da violência. Com isso, as instituições serão destituídas de qualquer sentido democrático, tornando-se figuras meramente decorativas. 
Assim como Montesquieu, que ressaltara, para cada forma de estado clássica, um princípio próprio - honra para a monarquia, virtude para a república etc. (Montesquieu, 1951) -, Hannah Arendt procura o princípio dos regimes totalitários. Ela encontra isso no terror. "O terror aniquila todas as relações entre os homens através da destruição do espaço da liberdade" (Arendt, 2009a, p. 970). Sistemas totalitários corrompem a esfera pública, conduzindo ao abandono do ser humano dentro de uma sociedade atomizada. Com isso, o indivíduo sofre uma dupla perda - a perda do mundo público e a perda do mundo privado. Primeiro se perde o cidadão, depois, o próprio homem (Arendt, 2009a, p. 663-702).

Isso mostra que essa patologia do totalitarismo pode ser intensificada. Ela culmina na criação de campos de concentração. Aqui, não somente o humano será eliminado, mas também toda e qualquer lembrança dele. A perversão extrema do poder total atinge seu apogeu em um "sistema do esquecimento" (Arendt, 2009a, p. 929). Perante tais abismos e aspectos sombrios do poder - haveria ainda outro caminho? Não seria o poder algo essencialmente ligado ao mal? Como expressão até mesmo do mal radical ou de sua suposta banalidade? (Arendt, 1999).

A obra filosófica de Hannah Arendt não atende a essa expectativa. Sua principal obra, A condição humana (Arendt, 1965, 1960), coloca a pergunta do poder sob uma perspectiva diferente. A patologia desemboca em uma fenomenologia do poder. Por meio da reflexão sobre as origens da política nos gregos, ela demonstra o que o poder foi e o que ele poderá ser. $A$ condição humana quer renovar o conceito de política a partir do espírito da antiguidade - política, isto é: a ação dos cidadãos no espaço público. Nesse espaço, Arendt encontra o lugar mágico do poder. Somente nesse entre, que é produzido no encontro dos cidadãos livres e iguais, o poder legítimo pode surgir: "O poder é o que mantém a existência da esfera pública, o espaço potencial de aparência entre homens que agem e que falam. [...] o poder surge entre os homens quando eles agem juntos e desaparece no momento em que se dispersam" (Arendt, 1965, p. 200). Hannah Arendt invoca a pureza da política. Para que o poder político brote, a partir de ações conjuntas, de forma não contaminada, o espaço público tem que estar hermeticamente fechado. Apenas assim o poder legítimo pode se afirmar contra as exigências do social e do privado. No fundo, Arendt vê o espaço público permanentemente ameaçado - não somente nas catástrofes do século XX. Já com a ascensão da 
sociedade - no começo dos tempos modernos -, a atrofia da política torna-se uma ameaça constante. A burocracia moderna aparece como um fantasma assustador, transformando os cidadãos em animais laborantes, e a política, em máquinas administrativas.

\begin{abstract}
Para avaliar a extensão da vitória da sociedade na era moderna - sua substituição inicial da ação pelo comportamento e a substituição posterior do governo pessoal pela burocracia, o governo de ninguém - pode convir lembrar que essa ciência inicial da economia, que substituiu padrões de comportamento apenas nesse campo um tanto limitado da atividade humana, foi seguida finalmente pela pretensão abrangente das ciências sociais que, como "ciências comportamentais", visam a reduzir o homem como um todo, em todas as suas atividades, ao nível de um animal condicionado e comportado (Arendt, 1965, p. 45).
\end{abstract}

Como, então, se criar uma esfera pública diante de tais tendências? E como garantir a criação autêntica do poder político? A proposta de Hannah Arendt é desafiadora. Sua aposta no poder comunicativo não conduz ao estado de direito democrático. Arendt suspeita da representação política e da política como vocação, pois ambas aliviam o cidadão do peso da existência política. $\mathrm{O}$ poder permanece legítimo apenas quando se encontra nas mãos dos citoyens. Arendt reconhece na república dos conselhos (Räterepublik) um refúgio em que o poder político pode resistir aos ataques do mundo moderno. Dessa forma, os exemplos históricos que Hannah Arendt nos apresenta tornam-se plausíveis. Ela não esconde sua simpatia pelas sociétés populaires na França revolucionária, pelos soviéticos russos, pela revolta popular húngara e pelos movimentos estudantis (cf. Arendt, 1988). Em todos esses casos, Arendt acredita descobrir a formação espontânea do poder como testemunhos vivos da liberdade no espaço público.

A revolta estudantil de 1968 também estimula Hannah Arendt a refletir, mais uma vez, sobre a questão. On violence, ou, em alemão, Macht und Gewalt ("poder e violência"), é o título para essa segunda defesa do poder político - defesa que é precedida por um ataque aos teóricos do poder. Todos esses não teriam, até agora, reparado a diferença fundamental entre poder e violência. Apenas quem identifica essa diferença específica está em condições de evitar a discriminação do poder e desmascarar ações não políticas como violência. De fato, Hannah Arendt eleva poder e violência a uma contradição irreconciliável: nesse contexto, poder representa as possibilidades positivas 
da política; e violência representa desvios da dominação política. Onde o poder governa não há lugar para a violência: "Conceitualmente falando, isso significa: o Poder é, de fato, essencial a todos os estados, inclusive a todos os tipos de grupos organizados, ao passo que a violência não o é. A violência é instrumental por natureza; assim como todos os meios e instrumentos, requer um fim, que orienta e justifica seu uso. [...] A violência bruta ocorre quando se perde o poder" (Arendt, 2009b, p. 52, 55).

Esse maniqueísmo tem seus pontos fortes, mas também muitos pontos fracos. De um lado, ele permite que as condições que instituem legitimidade política se tornem palpáveis, isto é, a garantia do espaço público. Raramente o sonho republicano de uma ação política comum foi tão vivo como em Hannah Arendt. Questionável é, entretanto, a defesa ofensiva do poder, uma vez que proíbe qualquer espécie de contato com a violência e, além disso, suspeita, em toda a parte, traições do poder. A violência é em si mesma algo mau, que não pode, de maneira alguma, ser reconhecido como momento necessário, nem mesmo como fenômeno marginal do poder. $\mathrm{O}$ poder instrumental, exigido por todo poder legítimo, está inserido inevitavelmente na esfera da violência - e não pode, portanto, ser preservado. A tentativa arendtiana de reabilitar o poder político torna-se dessa maneira um empreendimento questionável.

É, sem dúvida, tentador pensar um poder que se nutre somente da política comum e que consegue dispensar todo tipo de violência. Mas o preço a ser pago aqui pode ser muito alto - a saber, um grande distanciamento da realidade. O conceito de poder de Hannah Arendt deixa claras as falhas da política moderna. A fim de corrigi-las, ela prescreve à sociedade uma terapia draconiana. Para que o poder possa vir a ser aquilo que ele deve ser, a sociedade não pode permanecer o que ela é. A reflexão moderna sobre a antiguidade conduz, inevitavelmente, à aporia. A promessa de uma unidade entre política e poder revela-se, finalmente, boa demais para ser verdade. Ela cultiva apenas o mal-estar da modernidade.

\section{Michel Foucault ou onde o poder se torna visível}

Hannah Arendt descobre o lugar mágico do poder na esfera pública em que os seres humanos lutam, como cidadãos, por reconhecimento recíproco. Seu ideal hermético procura a proximidade com a antiguidade, e distancia-se dos instrumentos modernos de poder e de seus imaginários. Tal mal-estar 
diante da cultura moderna encontramos também em Michel Foucault. Entretanto, Foucault procura os cenários principais do poder não mais na antiguidade ou na era do totalitarismo, e sim na passagem do século XVIII para o XIX. Aqui, ele vê surgir um novo tipo de poder - e, ao mesmo tempo, o indivíduo moderno. Os novos heróis e vítimas da modernidade foucaultiana se chamam poder disciplinar e indivíduo disciplinar (Foucault, 1994).

O que significa disciplina Foucault sabe a partir de suas próprias vivências. Ele passa pelo adestramento da formação acadêmica de elite e se submete aos rituais da ciência. Em 1970, assume a cátedra na College de France, conquistando o centro do poder da inteligência acadêmica. Ao voltar-se para as ciências humanas e sociais, o filho de médico espera poder se libertar da herança do pai - mas fica, ainda assim, preso a ela. O nascimento da clínica é, como sabemos, o título de uma de suas primeiras obras. A relação entre doença e saúde, entre patologia e normalidade, entre exceção e regra - é isso o que vai ocupar Foucault ao longo de sua vida. Revelar, na marginalidade, o essencial é sua intuição teórica. Isso vale também e sobretudo para a seguinte questão: o que é o poder?

Alienação e sociedade, Vigiar e punir, O nascimento da clínica - já os próprios títulos denunciam a mudança na estratégia de pesquisa. Foucault não procura mais o poder em seu pretenso cerne, e sim o rastreia nas margens da sociedade. Não Versailles ou Champs Elysées, mas sim a clínica e a prisão serão, agora, as referências nessa nova topografia do poder. Não que a periferia se torne um novo centro do poder. O fato é que os mecanismos de poder permitem, aqui, ser mais facilmente diagnosticados. Não há mais espaço para lugares mágicos ou corpos simbólicos. O que caracteriza o poder moderno é muito mais a ausência de lugar e visibilidade. Por meio de uma microfísica, Foucault quer desvendar o véu do poder. Seu segredo será traduzido em uma fórmula nominalista: "O poder é o nome que se dá a uma situação complexa em uma sociedade" (Foucault, 1982, p. 114).

Essa definição nos faz lembrar vagamente Hannah Arendt. Também nela, o poder não é característica de um homem, de uma classe ou de uma instituição, mas sim um fenômeno relacional. Hannah Arendt pretendia compreender essas relações apenas dentro dos limites estreitos da esfera pública. Para Foucault, o poder encontra-se por toda parte. Ele não conhece lugares proibidos nem privilegiados para sua aparição. O poder governa em toda parte e em parte alguma. Ele lança uma rede sobre a sociedade. Nessa 
rede, todos os indivíduos encontram-se igualmente presos como objetos e sujeitos do poder. Todos estão "sempre em uma posição, na qual vivenciam e praticam esse poder simultaneamente... Em outras palavras: o poder não vai ser aplicado sobre os indivíduos, ele passa através deles" (Foucault, 1978, p. 82).

Embora descreva essa rede, às vezes, como sistema prisional, Foucault compreende o poder não como mero mecanismo de repressão. Também para ele, o poder encontra-se além do bem e do mal. O poder não é o mal radical, nem a corrupção dos seres humanos. Pelo contrário. O poder é inteiramente produtivo - ele transforma cada um em um indivíduo - em um sujet. A língua francesa, assim como o idioma português, sublinha a ambivalência da individualidade moderna. Sujet (sujeito) pode ser traduzido tanto por subordinado como por sujeito. Nessa zona de atrito entre submissão e autonomia, Foucault situa o surgimento do sujeito moderno. Subjetivação como humanização, normalização como individualização - com essas grandes palavras seria possível descrever a gênese do indivíduo moderno desde o Iluminismo. Como dissemos: Foucault privilegia o olhar sobre as margens da sociedade. Assim, essa gênese pode ser descrita de forma exemplar nas transformações das práticas penais na França do século XVIII e XIX (Foucault, 1994).

Antes da revolução, o infrator submetia-se a cruéis punições públicas e corporais. $\mathrm{O}$ ato público deveria tornar visível o poder do rei e, ao mesmo tempo, recuperar a ordem soberana. Após a revolução, o disciplinamento ocorre, ao contrário, na obscuridade; seu objeto não é mais o corpo, mas sim a alma - ela é disciplinada por meio do adestramento sutil do corpo. Tal poder disciplinar aparece como tipo ideal na visão do Panóptico, de Bentham. A arquitetura ideal da prisão deixa os inspetores invisíveis, e os controlados expostos ao olhar permanente do poder. Dessa forma, o controle invisível torna-se, finalmente, autocontrole. O poder visível passa a ser totalmente dispensável. Foucault não se cansa de acentuar a íntima ligação entre poder e conhecimento. Ambos trabalham lado a lado no disciplinamento do indivíduo. Assim, o trabalho corporal dos prisioneiros será analisado minuciosamente e sua execução, vigiada meticulosamente. "A partir dessa pequenez e mesquinhez", constata Foucault laconicamente, "nasceu o homem do humanismo moderno" (Foucault, 1994, p. 181). É óbvio que essa constatação ataca o projeto do Iluminismo nos seus sólidos fundamentos. A provocação é intencional. 
Foucault levanta veemente protesto contra as teorias modernas de poder desde Hobbes. Elas acobertaram o poder com concepções jurídicas de poder: entenderam mal as relações de poder como relações jurídicas e deixaram se deslumbrar pela figura do soberano. A cabeça do rei tem que rolar - essa é a máxima da pesquisa jacobina de Foucault. Não no corpo simbólico do rei, mas sim nos corpos disciplinados do indivíduo é que o poder se torna visível. Além disso, os teóricos modernos do poder se enganaram em seus princípios de fundamentação. Para Foucault, o poder não é mais um produto da ação coletiva. A lógica do contratualismo tem que ser invertida. Não são os indivíduos que produzem o poder e, sim, o poder que cria o indivíduo.

Por mais reveladora que possa parecer, a análise do poder de Foucault não pode ser confundida com uma crítica do poder em sentido próprio, pois, para Foucault - de modo muito semelhante a Maquiavel -, o poder se constitui de maneira autônoma: seu nomos não se submete a nenhuma outra lei. O poder não pode ser compreendido, valorado ou criticado de fora. Tudo que é já é submetido ao poder. A rede do poder em que o indivíduo moderno se encontra enlaçado, acaba, finalmente, aprisionando até mesmo o filósofo. De tal poder não há escapatória. O saber também não liberta - ao contrário: ele torna as malhas da rede ainda mais estreitas.

A crítica da modernidade empreendida por Foucault descarta prematuramente os instrumentos críticos necessários para colocar o próprio poder em questão. Direito, lei, vontade, liberdade, soberania - esses conceitos não podem sustentar nenhuma crítica no campo de poder da teoria foucaultiana. Para os princípios dos direitos humanos, para a autonomia e para a legitimidade democrática não há mais lugar. Foucault arruína o direito como meio de crítica do poder. Para fortalecer o projeto moderno a favor da própria modernidade, a história pós-moderna do indivíduo tem que ser reescrita. Também a pergunta do poder teria que ser novamente colocada. A última palavra sobre o poder não deveria ser a de Foucault.

\section{Referências}

ARENDT, Hannah (1960). Vita activa oder Vom tätigen Leben. Stuttgart: W. Kohlhammer.

Press.

(1965). The human condition. Chicago: University of Chicago 
(1988). Da revolução. São Paulo: Ática; Brasília: Editora da UnB. (1996). "Fernsehgespräch mit Günter Gaus", em LUDZ, Ursula (ed.). Ich will verstehen. München: Piper.

(1999). Eichmann em Jerusalém: um relato sobre a banalidade do mal. Trad. José Rubens Siqueira. São Paulo: Companhia das Letras. Beck. (2009a). Elemente und Ursprünge totaler Herrschaft. München: (2009b). Macht und Gewalt. München: Piper.

BURCKHARD, Jacob (2002 [1905]). "Weltgeschichtliche Betrachtungen", em Werke: kritische Gesamtausgabe, vol. 7. Basel: Schwabe.

CASSIRER, Ernst (1966). The myth of the State. London: New Haven. FOUCAULT, Michel (1978). Dispositive der Macht. Berlin: Merve Verlag. (1982). Sexualität und Wahrheit I. Frankfurt am Main: Suhrkamp. (1994). Überwachen und Strafen. Frankfurt am Main: Suhrkamp. HAMILTON, Alexander; MADISON, James \& JAY, John (2005). The federalist. With letters of Brutus. Cambridge: Cambridge University Press. HERB, Karlfriedrich (2005). "L'avenir de la république sur la lecture contractualiste de l'histoire chez Hobbes et Kant”, em FOISNEAU, Luc \& THOUARD, Denis (dirs.). De la violence à la politique: Kant et Hobbes. Paris: Librairie Philosophique J. Vrin.

HOBBES, Thomas (1839-1845): “A minute or first draught of the optiques", em The English works of Thomas Hobbes of Malmesbury, vol. 7. Edição de William Molesworth. London: Bohn.

(1966). Vom Menschen. Vom Bürger. Hamburg: Felix Meiner.

(1967). Vom Körper (De corpore). Elemente der Philosophie I. Hamburg: Felix Meiner.

(1991). Leviathan. Cambridge: Cambridge University Press.

KOBUSCH, Theo \& OEING-HANHOFF, Ludger (1980). "Macht [I.]", em RITTER, Joachim \& GRÜNDER, Karlfried (eds.). Historisches Wörterbuch der Philosophie, vol. 5. Darmstadt: Wissenschaftliche Buchgesellschaft.

KÖNIG, René (1979). Niccolò Machiavelli: zur Krisenanalyse einer Zeitenwende. München: Carl Hanser. 
LOCKE, John (1990). Two treatises of government. Cambridge: Cambridge University Press.

MACHIAVELLI, Niccolò (1833): "Das Leben Castruccio Castracanis", em Sämtliche Werke, vol. 2. Edição de Johannes Ziegler. Karlsruhe: Groos. (1983). The discourses. London: Penguin.

(1988). The Prince. Cambridge: Cambridge University Press.

MONTESQUIEU, Charles-Louis de Secondat, Baron de la Brède et de (1951). De L'esprit de lois. Euvre Complètes. Edição de Roger Caillois. Paris: Gallimard.

ROUSSEAU, Jean-Jacques (1964). Du contrat social, ou, Principes du droit politique, em Euvre complètes, vol. 3. Edição de Bernard Gagnebin e Marcel Raymond. Paris: Gallimard.

STRAUSS, Leo (1958). Thoughts on Machiavelli. Glencoel: The Free Press. WEBER, Max (1922). Wirtschaft und Gesellschaft. Tübingen: Mohr.

\section{Resumo}

O poder é mau por natureza? Está sempre em mãos erradas? Não. Essa é a resposta dada pelos clássicos da política moderna, Nicolau Maquiavel e Thomas Hobbes. Maquiavel desconfia das promessas antigas do bom regime e da virtude humana. Ele baseia o poder político na produtividade do mal. Apesar de compartilhar o profundo pessimismo antropológico de Maquiavel, Hobbes baseia-se na virtude do soberano: o Leviatã suprime a guerra perpétua. No século XX a apologia filosófica pelo poder assume uma forma diferente. Hannah Arendt separa a violência instrumental do poder comunicativo, transformando a ágora num lugar mágico do poder. Contrariamente, Michel Foucault nega a existência de qualquer lugar privilegiado para ocorrência do poder. Para ele, o poder tornase uma rede de relações sociais combinando sujeição e criatividade de forma ambígua. Palavras-chave: poder; violência; legitimação; antropologia política; saber; virtude.

\section{Abstract}

Is power bad by nature? Is it always in the wrong hands? No. This is the answer given by the political classics of Modern Age, Niccolò Machiavelli and Thomas Hobbes. Machiavelli distrusts the ancient promises of good regime and human virtue. He bases political power on the productivity of the evil. Despite sharing Machiavelli's profound anthropological pessimism, Hobbes relies on the virtue of the sovereign: the Leviathan does away with 
perpetual war. In the $20^{\text {th }}$ century the philosophical apologia for power assumes a different shape. Hannah Arendt separates instrumental violence from communicative power, turning the agora into the magic place of power. Contrary to that, Michel Foucault denies the existence of any privileged place of power. For him, power becomes a network of social relationships ambiguously combining subjection and creativity.

Keywords: power; violence; legitimacy; political anthropology; knowledge; virtue.

Recebido em 13 de novembro de 2011.

Aprovado em 10 de julho de 2012. 